\title{
ANALISIS IMPLEMENTASI KEBIJAKAN BEBAN MENGAJAR GURU JENJANG SMP, SMA, DAN SMK DI DIY
}

\author{
Anik Septi Widyawati \\ Dinas Dikpora Daerah Istimewa Yogyakarta \\ anik.septi@yahoo.com
}

\begin{abstract}
Abstrak
Penelitian ini bertujuan mengkaji: (1) implementasi kebijakan terkait beban mengajar guru minimal 24 jam per minggu, (2) dampak kebijakan beban mengajar terhadap kualitas dan kinerja guru, dan (3) faktor-faktor pendukung dan penghambat pelaksanaan kebijakan beban mengajar guru di Daerah Istimewa Yogyakarta. Penelitian kebijakan ini menggunakan pendekatan kualitatif, dengan metode grounded theory. Pengumpulan data menggunakan pedoman wawancara dan studi dokumen yang hasilnya divalidasi melalui trianggulasi sumber dan teknik, serta member check. Hasil penelitian menunjukkan, kebijakan beban mengajar guru minimal 24 jam per minggu masih relevan dilaksanakan di sekolah. Sebagian besar guru telah memenuhi beban mengajar tersebut, sehingga berhak memperoleh tunjangan profesi yang berdampak pada peningkatan kinerja guru. Faktor penghambatnya adanya kebijakan lokal di kabupaten/kota (Kota Yogyakarta, Kab. Sleman dan Kab. Bantul) yang mengkaitkan tunjangan profesi dengan kehadiran guru di sekolah. Faktor pendukungnya dengan diberlakukannya K-2006 dan K-2013 serta peran kepala sekolah sangat berpengaruh dalam pembagian jam mengajar.
\end{abstract}

Kata kunci: beban mengajar, sertifikasi, tunjangan profesi

\section{AN ANALYSIS OF THE IMPLEMENTATION OF TEACHER'S TEACHING LOAD POLICY IN JUNIOR HIGH SCHOOL, SENIOR HIGH SCHOOL, AND VOCATIONAL HIGH SCHOOL IN SPECIAL REGION YOGYAKARTA}

\author{
Anik Septi Widyawati \\ Dinas Dikpora Daerah Istimewa Yogyakarta \\ anik.septi@yahoo.com
}

\begin{abstract}
This research aimed review to: (1) the implementation of policies related to teaching load of teachers at least 24 hours every week, (2) the impact of policies teaching load to the quality and performance of teachers, and (3) the factors that restrict and support the implementation of the policies in Daerah Istimewa Yogyakarta. This policy research used qualitative approaches with the grounded theory method. Data were collected using interview guidelines and the study of documents the results are validated through triangulation of sources and techniques, as well as member check. The results of this study demonstrate that the policy of the teacher's teaching load at least 24 hours every week is still relevant at schools. The restrictive factor in the teaching load policy is the existence of local policy that associates allowance with teachers attendance at schools (Kota Yogyakarta, Kabupaten Sleman dan Kabupaten Kulonprogo). The supporting factors are the use of two curricula i.e. Curriculum 2006 and Curriculum 2013, which will largely determine the load of teachers in each subject and the policy of the school principal who will greatly affect the fulfillment of teachers teaching load every week.
\end{abstract}

Keywords: load of teaching, certification, benefits of profession 


\section{Pendahuluan}

Pemerintah sudah berusaha memberikan kesejahteraan yang memadai bagi guru. Peningkatan kesejahteraan guru haruslah diimbangi dengan peningkatan kompetensi. Ini merupakan perhatian pemerintah terhadap guru dan akan memunculkan iklim kerja yang lebih optimal bagi para insan pendidikan di Indonesia. Keadaan ini akan sangat terkait dengan pemenuhan beban mengajar guru, jam kerja dan kinerja guru. Apabila guru dapat melaksanakan aturan jabatan guru dan penilaian kinerja guru secara baik, benar dan konsisten, maka para guru dipastikan akan sibuk sekali dengan berbagai aktivitas, kewajiban dan tanggung jawab sebagai seorang guru yang profesional, bermartabat dan sejahtera bisa tercapai.

Dalam dunia pendidikan kualitas guru yang baik akan sangat menentukan output dari peserta didik. Kualitas guru yang baik mempunyai kompetensi sebagai pendidik yang didukung dengan dedikasi dan tanggung jawab yang tinggi sehingga akan memenuhi ketentuan persyaratan dalam sertifikasi dan diikuti hak yang akan diterima guru.

Kebijakan yang berkembang saat ini berkaitan dengan pelaksanaan Kurikulum 2013 telah ada Permendikbud Nomor 160 Tahun 2014 tentang Berlakunya Kurikulum 2006 dan Kurikulum 2013, yang ditindaklanjuti oleh Surat dari Dirjen Pendidikan Dasar dan Dirjen Pendidikan Menengah Nomor 233/C/KR/2015 Tanggal 19 Januari 2014, bahwa sekolah yang telah melaksanakan Kurikulum 2013 selama 3 semester maka sekolah tersebut tetap melanjutkan dengan Kurikulum 2013, dan bagi sekolah yang baru melaksanakan 1 semester maka kembali ke kurikulum 2006. Semua guru baik yang sudah bersertifikasi maupun yang belum bersertifikasi harus memenuhi jam wajib mengajar minimal 24 jam. Pemenuhan jam wajib belajar terkait erat dengan Pengajuan Angka Kredit (PAK) bagi pegawai fungsional tertentu yang akan naik pangkat.

Kebijakan pelaksanaan kurikulum pada sekolah yang kembali melaksanakan
Kurikulum 2006 tersebut berimbas pada pemenuhan beben mengajar guru. Khusus bagi guru yang mendapat tugas tambahan, pemenuhan jam disesuaikan dengan Peraturan Pemerintah Nomor 74 tahun 2008 (Presiden RI, 2008) dan Pemendikbud No.mor 4 Tahun 2015 tertanggal 13 Februari 2015 (Mendikbud RI, 2015), sedangkan untuk pedoman penghitungan beban kerja guru diterbitkan oleh Dirjen Peningkatan Mutu Pendidik dan Tenaga Kependidikan (PMPTK) yang berkaitan dengan tugas tambahan bagi guru.

Sesuai dengan amanat Undang-Undang Nomor 14 Tahun 2005 tentang Guru dan Dosen pasal 35 ayat (2) dinyatakan bahwa "beban kerja guru mengajar sekurang-kurangnya 24 jam dan sebanyakbanyaknya 40 jam tatap muka per minggu" (Depdiknas, 2005). Peraturan Menteri Pendidikan Nasional Nomor 18 Tahun 2007 tentang Sertifikasi bagi Guru dalam Jabatan (Mendiknas RI, 2007) mengamanatkan bahwa "guru yang telah memperoleh sertifikat pendidik, nomor registrasi, dan telah memenuhi beban kerja mengajar minimal 24 jam tatap muka per minggu memperoleh tunjangan profesi sebesar satu kali gaji pokok". Tidak semua guru berada pada kondisi ideal dengan beban mengajar minimal 24 jam tatap muka per minggu. Oleh karena itu diperlukan suatu panduan penghitungan beban kerja bagi guru/sekolah/ dinas dalam pemenuhan wajib mengajar minimal 24 jam per minggu agar guru yang telah memiliki sertifikat pendidik memperoleh haknya, yaitu tunjangan profesi.

Guru yang belum memperoleh tunjangan profesi maka akan diikutsertakan dalam Pendidikan dan Latihan Profesi Guru (PLPG) yang diselenggarakan oleh Dinas Pendidikan Kabupaten/Kota dan Provinsi. Bagi guru yang telah lulus PLPG, mereka berhak mendapatkan tunjangan profesi.

Tunjangan profesi sah diberikan kepada mereka yang sudah sertifikasi, dengan syarat harus memenuhi tugas mengajar minimal 24 jam per minggu. Jumlah peserta didik yang kurang dan rombongan belajar yang kurang dapat menyebabkan 
guru tidak bisa mengajar 24 jam per minggu. Jumlah guru dalam satu sekolah yang mengampu mata pelajaran tertentu terlalu banyak juga akan menyebabkan seorang guru kekurangan jam, sehingga tidak dapat memenuhi beban mengajar 24 jam per minggu. Hal ini juga harus diperhatikan oleh pemangku kepentingan di bidang pendidikan untuk dapat mengatur penyebaran/penempatan pendidik sesuai dengan kebutuhan sekolah masing-masing.

Di Daerah Istimewa Yogyakarta yang merupakan Kota Pendidikan, menunjukkan bahwa jumlah guru SMP yang belum sertifikasi ada 3.282 orang, guru SMA yang belum sertifikasi ada 2.396 orang dan guru SMK yang belum bersertifikasi ada 3.620 orang. Hal ini menunjukkan masih ada guru yang belum memenuhi syarat sertifikasi (belum lulus PLPG dan belum memenuhi 24 Jam mengajar per minggu) sebagai syarat utama menerima tunjangan profesi.

Dari urain tersebut, maka permasalahan yang muncul perlu kiranya dilakukan sebuah kajian ataupun penelitian tetapi lebih diprioritaskan pada implementasi kebijakan beban mengajar guru 24 jam per minggu.

Identifikasi masalah pada penelitian ini adalah: (1) banyak guru yang harus mengajar lebih dari 24 jam per minggu, sehingga kesempatan untuk mengembangkan ilmu menjadi kurang, (2) tugas sampiran guru seringkali menambah beban guru dan meninggalkan kelas. (3) ada beberapa mata pelajaran (seperti mata pelajaran Bahasa Jawa dan TIK) yang tidak dapat masuk dalam dapodik sehingga berpengaruh dalam jumlah jam mengajar guru tidak memenuhi dapodik untuk mendapatkan tunjangan profesi. (4) semangat kerja guru yang belum memenuhi 24 jam mengajar ditengarai menurun. (5.) Berlakunya kembali kurikulum 2006 menyebabkan banyak guru yang kekurangan jam mengajar, sehingga harus mencari tambahan jam di sekolah lain.

Tujuan dari penelitian ini adalah: (1) mengkaji implementasi kebijakan terkait beban mengajar guru minimal 24 jam per minggu, (2) mengetahui dampak kebijakan beban mengajar terhadap kualitas dan kinerja guru (3) mengetahui faktor-faktor pendukung dan penghambat pelaksanaan kebijakan beban mengajar guru di Daerah Istimewa Yogyakarta.

Manfaat penelitian ini adalah: (1) manfaat teoretis sebagai sarana untuk mengkaji mengembangkan ilmu pengetahuan bidang manajemen pendidikan dan sebagai bahan kajian dan referensi bagi penelitian sejenis nantinya, (2) manfaat praktis adalah untuk meningkatkan mutu manajemen sumber daya manusia dan kinerja guru agar lebih optimal dan memberikan kontribusi yang positif dalam pengambilan kebijakan khususnya dalam bidang pendidikan.

\section{Metode Penelitian}

Penelitian ini merupakan penelitian yang berkaitan dengan kebijakan dengan pendekatan kualitatif. Alasan menggunakan pendekatan kualitatif adalah untuk menganalisis sejauh mana suatu kebijakan bisa diterima dalam masyarakat dan tidak menimbulkan gejolak dalam implementasinya, sehingga dapat memberikan dampak yang positif terhadap peningkatan kinerja guru.

Penelitian kualitatif adalah penelitian yang bermaksud untuk memahami fenomena tentang apa yang dialami oleh subjek penelitian misalnya perilaku, persepsi, tindakan dan lainnya yang secara holistik dan dengan cara deskripsi dalam bentuk katakata dan bahasa, pada suatu konteks khusus yang alamiah dan dengan memanfaatkan berbagai metode alamiah.

Salah satu pendekatan penelitian kualitatif yaitu dengan grounded theory, menurut Moleong (2014, pp. 26-27) maksud grounded theory adalah untuk mengembangkan teori tentang minat terhadap fenomena. Tetapi hal ini bukan hanya teoretisasi abstrak seperti yang mereka bahas. dalam hal ini teori perlu di-grounded atau berasal dari bawah dalam sesuatu pengamatan, sampai menjadi istilah. Penelitian dimulai dengan memunculkan pertanyaan 
generatif yang membantu penelitian namun tidak dimaksudkan untuk tetap statis atau menjadi dinamis.

Ada beberapa strategi analisis kunci yang dikembangkan: (1) Koding adalah proses untuk membuat kategorisasi data kualitatif dan juga untuk menguraikan implikasi dan rincian dari kategori-kategorinya. Pada awalnya seseorang memulai membuat koding dengan mempertimbangkan data yang secepatnya muncul secara rinci sementara ia mengambangkan beberapa koding lainnya. Kemudian, ia bergerak ke arah koding yang dipilih dengan mempertimbangkan secara sistematis kode-kode yang dikaitkan dengan konsep inti. (2) Memoing (membuat memo) adalah proses mencatat pemikiran-pemikiran dan gagasan-gagasan dari peneliti sewaktu halhal itu muncul. Memoing dilakukan secara ekstensif dalam catatan marginal dan tanggapan-tanggapan yang diberikan dalam catatan lapangan. Pembuatan memo cenderung menjadi terbuka dan kemudian barulah mengarah secara terfokus kepada konsep inti. (3) Diagram terpadu dan sesi digunakan untuk menarik seluruh rincian menjadi satu, untuk membantu agar data itu menjadi berarti dengan mengarahkan diri kepada teori yang muncul. Diagram dapat berbentuk grafik yang bermanfaat pada waktu itu dalam pengembangan teori. Pekerjaan keterpaduan ini dilakukan dengan baik dalam diskusi-diskusi kelompok dimana anggota kelompok dapat memberikan pendapatnya atau pandangan terhadap teori yang selama ini telah muncul.

Penelitian ini mengambil lokasi di Daerah Istimewa Yogyakarta. Waktu penelitian dimulai dengan pengambilan data di lapangan yang dilaksanakan pada bulan Januari-April 2015. Subjek penelitian ini adalah guru PNS yang dapat memberikan informasi berkaitan dengan judul penelitian tentang Implementasi Kebijakan Beban Mengajar Guru Pada Jenjang Sekolah Menengah Pertama, Sekolah Menengah Atas dan Sekolah Menengah Kejuruan, di Daerah Istimewa Yogyakarta, dengan jumlah responden 20 orang, dengan asumsi data yang diambil merupakan orang yang tau tentang kebijakan beban mengajar guru minimal 24 jam per minggu atau menggunakan sample purposif, dimana data tersebut adalah data yang berulang-ulang sampai pada titik jenuh. Responden merupakan perwakilan guru dari tiap kabupaten/kota di Daerah Istimewa Yogyakarta.

Data penelitian ini dikumpulkan dengan wawancara dan studi dokumen. Wawancara dilakukan kepada subjek penelitian yang meliputi guru/kepala sekolah pada jenjang Sekolah Menengah Pertama, Sekolah Menengah Atas, dan Sekolah Menengah Kejuruan secara mendalam untuk mengungkap sejauh mana kebijakan yang dikeluarkan pemerintah dapat diimplementasikan di lapangan dan kendala apa yang dihadapi guru dalam pemenuhan 24 jam per minggu. Studi dokumen dilakukan untuk mempelajari dan memahami tentang dokumen yang berupa regulasi dan referensi yang mendukung dan berkaitan dengan beban mengajar minimal 24 jam tatap muka per minggu di sekolah.

Dokumen yang diambil merupakan bagian dari penelitian dan diperoleh melalui pengumpulan dokumen di sekolah yang berkaitan dengan data pemenuhan beban mengajar 24 jam dan dokumen yang berupa regulasi/aturan baik yang ada di tingkat sekolah, kabupaten/kota dan provinsi. Dokumen ini sangat dibutuhkan dalam mendukung penelitian yang sedang dilakukan bisa dalam bentuk hardcopy maupun softcopy.

Teknik analisis data dalam penelitian ini merujuk pada (Moleong, 2014, p. 288), yakni menggunakan metode perbandingan tetap atau Constant Compatarive Method karena dalam analisis data secara tetap membandingkan satu datum dengan datum yang lain, dan kemudian secara tetap membandingkan kategori dengan kategori lainnya. Teknik analisis data ini juga dinamakan Grounded Research. Namun secara umum analisis datanya mencakup: reduksi data, kategorisasi data, sintesisasi, dan diakhiri dengan menyusun hipotesis kerja, yaitu sebagai berikut. Pertama, adalah reduksi data adalah identifikasi satuan (unit). Pada mulanya diidentifikasikan ada- 
nya satuan yaitu bagian terkecil yang ditemukan dalam data yang memiliki makna bila dikaitkan dengan fokus dan masalah penelitian dan sesudah satuan diperoleh, langkah berikutnya adalah membuat koding. Membuat koding berarti memberikan kode pada setiap 'satuan' agar supaya tetap dapat ditelusuri data/satuannya, berasal dari sumber mana. Kedua, Kategorisasi adalah menyusun kategori. Kategorisasi adalah upaya memilah-milah setiap satuan ke dalam bagian-bagian yang memiliki kesamaan dan setiap kategori diberi nama yang disebut 'label'. Ketiga, sintesisasi adalah mensintesiskan berarti mencari kaitan antara satu kategori dengan kategori lainnya dan kaitan satu kategori dengan kategori lainnya diberi nama atau label lagi. Keempat, menyusun 'Hipotesis Kerja' adalah hal ini dilakukan dengan merumuskan suatu pernyataan yang proporsional. Hipotesis kerja ini merupakan teori subtantif (yaitu teori yang berasal dan masih terkait dengan data. Secara garis besar analisis data menurut metode perbandingan tetap adalah seperti yang dikemukakan tersebut.

Teknik pemeriksaan keabsahan data digunakan untuk mengecek kebenaran data yang dihasilkan sehingga diperoleh data yang valid dan dapat dipertanggungjawabkan keabsahannya. Teknik pemeriksaan keabsahan data (Sugiyono, 2014, p. 366) dalam penelitian kualitatif salah satunya dengan Uji Kredibility, yang dilakukan dengan perpanjangan pengamatan, peningkatan ketekunan dalam penelitian, tringulasi, diskusi dengan teman sejawat, analisis kasus negatif dan member check. Dalam penelitian ini akan digunakan uji kredibility dengan trianggulasi. Wiersma menjelaskan bahwa Triangulation is qualitative cross-validation. It assesses the sufficiency of the data according to the convergence of multiple data sources or multiple data collection procedures (Sugiyono, 2014, pp. 372-374). Triangulasi dalam pengujian kredibilitas ini diartikan sebagai pengecekan data dari berbagai sumber dengan berbagai cara dan berbagai waktu. Dengan demikian terdapat triangulasi sumber, triangu- lasi teknik pengumpulan data, dan triangulasi waktu. Dalam penelitian ini menggunakan trianggulasi sumber.

\section{Hasil Penelitian dan Pembahasan}

\section{Deskripsi Hasil Penelitian}

Keterlaksanaan kebijakan beban mengajar guru di Daerah Istimewa Yogyakarta

Kebijakan publik (public policies) merupakan rangkaian pilihan yang kurang lebih saling berhubungan (termasuk keputusan-keputusan untuk bertindak) yang dibuat oleh badan atau pejabat pemerintah, diformulasikan di dalam bidang-bidang strategis.

Masalah kebijakan tergantug pada pola keterlibatan pelaku kebijakan (policy stakeholder) yang khusus yaitu para indivi$\mathrm{du}$ atau kelompok individu yang mempunyai andil dalam kebijakan karena mereka mempengaruhi dan dipengaruhi oleh keputusan pemerintah. Pelaku kebijakan sering menangkap secara berbeda informasi yang yang sama mengenai lingkungan kebijakan.

Menurut Weimer \& Vining (2011, p. 167) menyatakan bahwa:

The practice perspective in policy analysis implish not only a change in the level (micro versus macro) or in direction of analysis (buttom up instead of top down), but much wider and more profound, a parallel change in quality focus and in the stance towards political actors, those officials, administrators and citizens who through their actions and interest populate public life.

Dalam perspektif praktik analisis kebijakan tidak hanya perubahan tingkat (mikro terhadap makro) atau ke arah analisis (dari bawah bukan dari atas), namun lebih luas dan lebih mendalam, perubahan paralel dalam fokus kualitas dan sikap terhadap aktor politik, para pejabat, administrator dan warga melalui tindakan dan kepentingan mereka mengisi kehidupan publik. Peran publik sangat penting dalam mempengaruhi kebijakan yang sesuai dan dapat diterima oleh semua pihak. 
Menurut Tilaar \& Nugroho, (2012, pp. 140-155) kebijakan pendidikan sebagai implementassi ilmu pendidikan dan praktik dapat diringkas yaitu kebijakan mempunyai makna yang esensial. Menurut Hiley \& Soenarto $(2013$, p. 92) tahap evaluasi output dan outcome kebijakan (The evaluation of policy outputs and outcomes) adalah tahap mengevaluasikan hasil dan dampaknya.

Dalam Peraturan Menteri Pendidikan dan Kebudayaan Nomor 62 Tahun 2013 tentang sertifikasi guru dalam jabatan dalam rangka penataan dan pemerataan guru, pasal 1 ayat (5) disebutkan bahwa "sertifikasi adalah proses pemberian sertifikat pendidik untuk guru". Ayat (6) menyatakan "tunjangan profesi guru adalah tunjangan yang diberikan kepada guru sesuai dengan sertifikat profesinya dan pemenuhan beban jam mengajar" (Mendikbud RI, 2013). Sedangkan Peraturan Menteri Pendidikan Nasional Nomor 39 Tahun 2009 tentang pemenuhan beban kerja guru dan pengawas satuan pendidikan pasal 1 ayat (1) menyatakan bahwa:

Beban kerja guru paling sedikit ditetapkan 24 (dua puluh empat) jam tatap muka dan paling banyak 40 (empat puluh) jam tatap muka dalam 1 (satu) minggu pada satu atau lebih satuan pendidikan yang memiliki izin pendirian dari pemerintah atau pemerintah daerah (Mendiknas RI, 2009).

Menurut (Cohen, Brody, \& SaponShevin, 2004, p. 9) menyatakan bahwa:

The program descriptions deal with the daily realities and complexities of running courses, program and teacher education models that have cooperative learning at their core, each chapter summerizes what the authors learned from their program and the implication of teacher education programs.

Pendidikan guru sangat menentukan kualitas dan kompetensi seorang guru dalam memberikan materi kepada peserta didik, dengan mengembangkan pembelajaran yang kooperatif pada setiap program, maudel, dan memberikan resume pada setiap materi yang disampaikan.
Saat ini berlaku dua kurikulum yaitu Kurikulum Tingkat Satuan Pendidikan (KTSP) atau biasa disebut Kurikulum 2006 dan Kurikulum 2013. Hal ini sangat mempengaruhi pola dan metode dalam penentuan jumlah jam mengajar/jam tatap muka untuk tiap mata pelajaran dalam setiap satuan pendidikan. Dari beberapa narasumber guru dan kepala sekolah yang sudah diwawancara menyampaikan kondisi di sekolah masing-masing dengan kurikulum yang digunakan saat ini.

Di DIY saat ini hampir semua guru telah memenuhi beban mengajar 24 jam per minggu.

Dampak Kebijakan Beban Mengajar Guru terhadap Kualitas dan Kinerja Guru di Daerah Istimewa Yogyakarta.

American Council on Education (2004, p. 2) menyatakan bahwa:

The college of education was established in 1915. It offer both teacher certification program and academic program which do not lead to teacher certification. Students who have already earned undergraduate degree and want to pursue teacher certification may work with teacher education services for either a second undergraduate degree or the non traditional master's certification program.

Perguruan tinggi pendidikan didirikan pada tahun 1915, menawarkan baik program sertifikasi guru dan program akademik yang tidak mengarah ke sertifikasi guru. Mahasiswa yang telah mendapatkan gelar sarjana dan ingin mengejar sertifikasi guru dapat bekerja dengan layanan pendidikan guru baik untuk gelar sarjana kedua atau program sertifikasi master non tradisional. Hal ini menunkjukkan bahwa program sertifikasi guru sudah ada sejak tahun 1915. Perguruan tinggi pendidikan mempunyai peran yang penting dalam mendukung kebijakan yang diambil pemerintah, dengan menawarkan baik program sertifikasi guru dan program akademik yang tidak mengarah ke sertifikasi guru. Siswa yang telah mendapatkan gelar sarjana dan ingin mengejar sertifikasi guru dapat bekerja dengan layanan pendidikan guru baik un- 
tuk gelar sarjana kedua atau program sertifikasi master non tradisional.

Kebijakan tentang sertifikasi menurut Altsbuler \& Webb (2009, p. 4) menyatakan bahwa:

The certification standards presented in this article are a reflection of the current reality in the field, school social work lags behind school counseling and school psychology incarving out self-defined niche with consistent expectations and responsibilities. Clarifying professional preparation and competencies is one key to enhancing legitimacy for the school social work profession.

Standar sertifikasi merupakan refleksi dan realitas di lapangan, kegiatan di sekolah merupakan tanggung jawab yang harus dijalani secara konsisten. profesional dan konsisten merupakan salah satu kunci untuk meningkatkan legitimasi profesi pendidik di sekolah. Sehingga dapat dikatakan bahwa sertifikasi menjadi salah satu bukti profesi seseorang telah memperoleh legitimasi secara nyata dan dapat dipertanggungjawabkan kepada publik.

Setiap kebijakan yang diambil oleh pemerintah pasti akan membawa dampak, baik positif maupun negatif. Dengan adanya beban mengajar 24 jam per minggu yang merupakan syarat sertifikasi sehingga dapat menerima tunjangan profesi maka sebagian besar kinerja guru semakin meningkat. Guru menjadi lebih disiplin, semangat, bertanggung jawab, berdedikasi dan lebih sejahtera.

Faktor-faktor Penghambat dan Pendukung Keterlaksanaan Kebijakan Mengajar di Daerah Istimewa Yogyakarta

Adanya pemberlakuan dua kurikulum saat ini, tentu saja akan dapat mempengaruhi pola penentuan jumlah jam mengajar setiap mata pelajaran dalam setiap satuan pendidikan di Daerah Istimewa Yogyakarta. Pelaksanaan dua kurikulum yaitu Kurikulum 2013 dan Kurikulum 2006 maka akan berpengaruh terhadap pemenuhan beban mengajar guru setiap mata pelajaran yang diampu baik yang ada pada satuan pendidikan SMP, SMA, dan SMK di Dearah Istimewa Yogyakarta.

Pembahasan

Keterlaksanaan Kebijakan Beban Mengajar Guru di Daerah Istimewa Yogyakarta

Dalam Peraturan Menteri Pendidikan Nasional Nomor 39 Tahun 2009 tetang pemenuhan beban kerja guru dan pengawas satuan pendidikan pasal 1 ayat (1) menyatakan bahwa:

Beban kerja guru paling sedikit ditetapkan 24 (dua puluh empat) jam tatap muka dan paling banyak 40 (empat puluh) jam tatap muka dalam 1 (satu) minggu pada satu atau lebih satuan pendidikan yang memiliki izin pendirian dari pemerintah atau pemerintah daerah (Mendiknas RI, 2009)

Berkaitan dengan hal di atas dapat dikatakan bahwa sebagian besar guru di Daerah Istimewa Yogyakarta baik guru jenjang SMP, SMA dan SMK telah memenuhi beban mengajar 24 jam per minggu, yang merupakan salah satu syarat sertifikasi guru, sehingga dapat memperoleh tunjangan profesi. Banyak cara yang dilakukan satuan pendidikan agar guru dapat memenuhi 24 jam mengajar per minggu, yaitu dengan berkoordinasi dengan sekolah sekitarnya, membuat kesepakatan dengan guru yang satu jurusan atau mata pelajaran yang sama, menambah rombel, mengindentifikasi guru yang belum memenuhi jam mengajar yang selanjutnya diberikan tugas tambahan sebagai kepala perpustakaan atau kepala laboratorium untuk dapat memenuhi 24 jam per minggu. Dengan adanya ekuivalensi tugas/jabatan dalam satuan pendidikan sangat membantu untuk memenuhi beban mengajar 24 jam per minggu. Menurut hasil penelitian yang dilakukan oleh Bank Dunia dalam USAID (2014, p. 10) disebutkan bahwa:

Ketidakmerataan guru mempunyai dampak negatif pada dua hal. Pertama, pelayanan publik bidang pendidikan di sekolah-sekolah yang kekurangan guru menjadi tidak maksimal karena pada jam pelajaran banyak kelas dibiarkan kosong tanpa ke- 
giatan belajar, kriteria ketuntasan mengajar tidak tercapai, dan akhirnya kompetensi murid manjadi rendah. Kedua, guruguru yang bertugas di sekolah-sekolah yang berkelebihan guru menjadi 'idle' dan tidak dapat memenuhi jumlah jam mengajar sesuai standar (24 jam per minggu) karena harus berbagi dengan guru lainnya. Keadaan ini menimbulkan kerugian pada guru karena berpengaruh pada pengembangan karir guru, yakni sertifikasi dan kenaikan pangkat yang mensyaratkan terpenuhinya jam mengajar.

Untuk Daerah Istimewa Yogyakarta, pada sekolah-sekolah tertentu masih kekurangan guru, namun hal ini dapat diatasi dengan mengangkat guru tidak tetap yang dibiayai oleh komite sekolah. Apabila ada guru yang masih kekurangan jam mengajar maka akan memenuhi jam mengajarnya di sekolah lain atau mempunyai tugas tambahan sebagai wakil kepala sekolah, kepala perpustakaan, kepala laboratorium, atau kepala bengkel.

Perhitungan beban kerja guru adalah bagian tak terpisahkan dari perencanaan kebutuhan guru dalam perencanaan sekolah seutuhnya. Terpenuhi atau tidaknya beban mengajar 24 jam tatap muka per minggu bagi jenis guru tertentu sebenarnya sudah dapat dideteksi pada saat jumlah guru yang dibutuhkan sudah dihitung. Kebijakan beban mengajar guru ini diambil oleh pemerintah dengan berbagai pertimbangan baik positif dan negatifnya.

Dampak Kebijakan Beban Mengajar Guru terhadap Kualitas dan Kinerja Guru di Daerah Istimewa Yogyakarta

Sebagian besar guru yang telah diwawancarai mengungkapkan bahwa setelah menerima tunjangan profesi mempunyai kinerja yang semakin meningkat daripada sebelum menerima tunjangan profesi, dalam bentuk guru lebih disiplin, lebih tertib administrasi, lebih semangat, senang, lebih berkecukupan, tidak terbebani dengan urusan sosial, bisa fokus pada pekerjaan, sebagian digunakan untuk menunjang sarana pembelajaran dengan membeli (laptop, LCD, speaker), melanjutkan sekolah
S2, dan ada kontribusi menjadi lebih baik (keteladanan). Namun ada sebagian yang kinerjanya masih stagnan walaupun sudah menerima tunjangan profesi, khususnya bagi guru-guru usia tua. Dengan adanya tunjangan profesi ini lebih banyak nilai positifnya daripada negatifnya.

Faktor-Faktor Penghambat dan Pendukung Keterlaksanaan Kebijakan Beban Mengajar Guru di Daerah Istimewa Yogyakarta.

Dari hasil penelitian yang dilakukan oleh Bank Dunia tahun 2014 di beberapa daerah seperti di Kabupaten Luwu, Kabupaten luwu Utara, Kabupaten Barru, Kabupaten Aceh Singkil, Kabupaten Bondowoso, dan Kabupaten Sambas menyatakan bahwa pemberian tunjangan profesi yang diberikan kepada guru belum berpengaruh secara signifikan terhadap peningkatan kinerja guru di daerah tersebut. Hal ini tentu saja berbeda dengan keadaan di Daerah Istimewa Yogyakarta, yang pada dasarnya di Daerah Istimewa Yogyakarta adanya tunjangan profesi dapat meningkatkan kinerja guru yang ditandai dengan guru lebih disiplin, bertanggung jawab, bersemangat, berdedikasi dan lebih sejahtera. Namun demikian masih ada beberapa guru yang masih memiliki kinerja stagnan terutama guru yang usia tua (hampir pensiun).

Menurut OECD-ADB (2015, p. 277) menyatakan bahwa:

International studies show that the quality of leadership and management has a major impact on teacher motivation, the quality of teaching and learning and the relationships with parents and the community. Highly skilled leadership, high expectations and action taken to tackle poor attendance and below-standard classroom practice are likely to be the main drivers for change.

Studi internasional menunjukkan bahwa kualitas kepemimpinan dan manajemen memiliki dampak besar pada motivasi guru, kualitas mengajar dan belajar dan hubungan dengan orang tua dan masyarakat. Pemimpin yang mempunyai keterampilan yang tinggi, harapan yang tinggi dan 
tindakan yang diambil untuk mengatasi permasalahan yang buruk dan kelas praktik di bawah standar cenderung menjadi pendorong utama untuk berubah. Keberhasilan suatu kebijakan dan program tidak lepas dari pengaruh seorang pemimpin untuk mengarahkan dan mendorong bawahannya untuk menjadi lebih baik.

Salah satu faktor penghambatnya adalah kebijakan di tingkat daerah berkaitan dengan penerimaan tunjangan profesi yang dihubungkan dengan presensi kehadiran. Hal ini tentu saja sangat memberatkan guru, dan solusi yang diberikan juga memberatkan siswa sebagai peserta didik. Kebijakan daerah ini hanya diterapkan di Kota Yogyakarta, Sleman dan Kulonprogo. Sebagian guru juga menyatakan bahwa beban mengajar 24 jam per minggu itu masih berat, idealanya adalah 18 jam per minggu dengan asumsi guru masih punya waktu untuk mengembangkan kompetensinya, melakukan penelitian atau kegiatan lain yang mendukung Pengembangan Keprofesian Berkelanjutan (PKB). Untuk saat ini tugas guru tidak hanya melaksanakan Kegiatan Belajar Mengajar (KBM) tetapi juga melakukan persiapan, perencanaan, pelaksanaan, penilaian dan evalusai terhadap peserta didik. Kegiatan ini semua dilakukan diluar jam belajar, sehingga apabila menganjar 24 jam per minggu maka waktu sudah sangat penuh hanya untuk mengajar di kelas. Apabila seorang guru tidak masuk dikarenakan sakit (opname di rumah sakit) dan telah ditunjukkan dengan surat keterangna dokter, dengan adanya kebijakan daerah tetap saja harus mengganti jam di lain waktu di luar jam pelajaran. Hal ini menunjukkan bahwa kebijakan tersebut terasa tidak manusiawi dan sangat memberatkan peserta didik, karena harus menambah jam pelajaran lagi di sore hari hanya demi memenuhi beban jam mengajar guru yang tidak masuk. Apabila seorang guru tidak masuk dikarenakan sakit bukan berarti guru tersebut tidak profesional.

Sedangkan faktor pendukungnya adalah banyak guru yang tidak kekurangan jam mengajar, dalam arti permasalahan kekurangan jam dapat diatasi dengan kesepakatan semua pihak dan tidak ada yang dirugikan. Penggunaan kembali kurikulum 2006 bagi sebagian sekolah menjadi lebih mudah untuk memenuhi beban mengajar guru minimal 24 jam per minggu.

Dari uraian tersebut dapat dikatakan bahwa sebagain besar sekolah kembali pada Kurikulum 2006, hal ini membawa dampak positif juga bagi guru mata pelajaran tertentu karena beban mengajar per minggu sudah dapat dipenuhi di sekolah, namun ada beberapa guru yang menjadi kelebihan jam. Sedangkan salah satu faktor penghambatnya adanya kebijakan daerah terkait dengan penerimaan tunjangan profesi yang dihubungkan dengan kehadiran guru di sekolah.

\section{Keterbatasan Penelitian}

Dalam penelitian ini masih memiliki beberapa kelemahan, antara lain: 1 . Peneliti tidak dapat memilih responden yang memiliki kualitas yang memadai, sesuai yang dikehendaki sehingga dapat memberikan banyak masukan, namun terkadang mendapat responden yang menjawab saat ditanya, dan tidak dapat memberikan argumen yang lebih luas. 2. Guru yang diambil telah mewakili dari lima kabupaten/kota, namun jumlahnya masih terbatas dibandingkan dengan jumlah seluruh guru di DIY pada jenjang SMP, SMA, dan SMK berjumlah 11.010 orang.

\section{Simpulan dan Saran}

Berdasarkan pembahasan hasil penelitian yang telah diuraikan maka dapat disimpulkan bahwa kebijakan beban mengajar guru untuk saat ini masih relevan diimplementasikan pada Sekolah Menengah Pertama, Sekolah Menengah Atas dan Sekolah Menengah Kejuruan di Daerah Istimewa Yogyakarta.

Keterlaksanaan Kebijakan Beban Mengajar Guru di Daerah Istimewa Yogyakarta

Pelaksanaan kebijakan beban mengajar guru jenjang SMP, SMA, dan SMK di Daerah Istimewa Yogyakarta saat ini dapat 
diimplementasikan dan masih relevan dilaksanakan di sekolah. Sebagian besar guru dapat memenuhi beban mengajar minimal 24 jam per minggu, sebagai salah satu syarat sertifikasi. Dengan ketentuan tersebut maka guru berhak menerima tunjangan profesi sebesar satu kali gaji. Namun demikian ada beberapa guru mata pelajaran Olahraga dan agama masih kelebihan jam mengajar (lebih dari 24 jam per ming$\mathrm{gu})$, karena dalam satu sekolah guru mata pelajaran tersebut masih terbatas jumlahnya, sehingga harus mengampu semua kelas, ada guru yang dalam satu minggu harus mengampu 30 jam per minggu, dan kelebihan jam mengajar ini tidak diperhitungkan dalam kaitannya dengan penerimaan tunjangan profesi. Sedangkan guru Teknologi Informasi (TI) pada jenjang SMP, SMA, dan SMK yang menggunakan kurikulum 2006 tetap mendapatkan jam mengajar, namun bagi sekolah yang telah menggunakan kurikulum 2013 maka perhitungan beban mengajar sesuai dengan perhitungan guru bimbingan konseling dan diminta untuk membantu pada kegiatan yang berkaitan dengan data dan informasi di sekolah.

Dampak Kebijakan Beban Mengajar Guru terhadap Kualitas dan Kinerja Guru di Daerah Istimewa Yogyakarta.

Guru yang telah sertifikasi telah mendapat tunjangan profesi sebesar satu kali gaji, dan sebagian besar guru yang telah menerima tunjangan profesi memiliki kinerja yang lebih baik dari sebelumnya. Hal ini dibuktikan dengan sikap lebih semangat, lebih disiplin, tidak risau dengan urusan sosial, lebih konsentrasi dalam menjalankan tugas, tanggung jawab, dan lebih tertib dalam administrasi. Namun demikian peran manajemen kepemimpinan dari kepala sekolah, pengawas dan pengambil kebijakan di tingkat atas sangat berpengaruh dalam meningkatkan kinerja dan kualitas keprofesiannya. Hal ini dibuktikan dengan peran kepala sekolah dalam membudayakan iklim kerja di sekolah dan memberikan pengarahan akan sangat berpengaruh pada kinerja guru.
Peran pengawas sekolah dalam membina, membimbing, dan memberikan penilaian guru akan sangat mempengaruhi kinerja guru yang bersangkutan. Kebijakan daerah yang berada di Pemerintah Kabupaten/ Kota juga sangat membawa dampak bagi kinerja dan kualitas guru.

Dari data yang diambil terdapat preposisi teoritik yang berkaitan dengan dampak kebijakan beban mengajar guru terhadap kualitas dan kinerja guru: (1) implementasi kebijakan sertifikasi guru dapat meningkatkan kinerja guru, (2) beban tugas mengajar guru berpengaruh terhadap pelaksanaan Pengembangan Keprofesian Berkelanjutan (PKB), (3) Kepemimpinan kepala sekolah berpengaruh terhadap pembagian jam mengajar guru, (4) pemberlakuan jenis Kurikulum 2006 atau Kurikulum 2013 berpengaruh terhadap pencapaian jumlah jam mengajar, (5.) Kebijakan setempat/lokal (kabupaten/kota) yang berkaitan dengan sertifikasi cenderung memberatkan guru, (6) kebijakan beban mengajar guru 24 jam per minggu berdampak pada penambahan beban belajar siswa, (7) intensitas pembinaan pengawas satuan pendidikan dapat meningkatkan kompetensi guru dan kualitas pembelajaran. (8.) Keprofesionalan guru tidak bisa diukur dari jumlah beban mengajar saja.

Faktor-Faktor Penghambat dan Pendukung Keterlaksanaan Kebijakan Beban Mengajar Guru di Daerah Istimewa Yogyakarta.

Faktor penghambatnya selain dengan adanya kebijakan daerah masing-masing kabupaten/kota yang membuat aturan bahwa guru yang sudah sertifikasi akan dikaitkan dengan tingkat kehadiran di sekolah, bila tidak masuk kerja selama 1 hari lebih dan tidak dapat mengganti jam mengajar maka guru tersebut akan kehilangan tunjangan profesi selama satu bulan. Apabila tidak masuk dikarenakan sesuatu hal maka guru harus mengganti jam yang ditinggalkan tersebut di lain hari diluar jam belajar. Hal ini tentu saja aturan yang sangat memberatkan bagi seorang guru dan murid, karena murid harus memenuhi jam mengajar guru di luar jam pelajaran. Hal 
ini dapat dikatakan bahwa guru yang tidak masuk karena keadaan yang mendesak (sakit) belum tentu guru tersebut tidak profesional dalam menjalankan tugasnya, dan tidak berhak mendapatkan tunjangan profesi, yang seharusnya menjadi haknya.

Faktor pendukungnya penggunaan Kurikulum 2013 dan Kurikulum 2006 sangat berpengaruh dalam menentukan beban mengajar guru pada setiap mata pelajaran yang diampu oleh guru dalam satuan pendidikan. Selain itu juga kebijakan pimpinan dalam satuan pendidikan untuk menentukan pembagian jam mengajar akan sangat mempengaruhi pemenuhan beban mengajar guru per minggu.

Dengan memperhatikan hasil penelitian, dan implikasi yang diajukan, selanjutnya dapat diajukan rekomendasi bagi pengambil kebijakan dan penelitian lanjutan. Rekomendasi bagi pengambil kebijakan pendidikan adalah sebagai berikut. Pertama, perlu adanya evaluasi terhadap kebijakan daerah di tingkat Kabupaten/ Kota khusunya Kota Yogyakarta, Kabupaten Sleman, dan Kabupaten Bantul yang membuat kebijakan berupa pemberian tunjangan profesi yang dikaitkan dengan tingkat kehadiran guru di sekolah, hal ini dikarenakan tidak semua daerah menggunakan kebijakan tersebut, sehingga hal ini tentu saja sangat memberatkan guru yang ada di daerah tersebut. Kedua, pemerintah pusat perlu melakukan evaluasi terhadap penerima tunjangan profesi yang selama ini belum pernah dilakukan.

Rekomendasi bagi penelitian lanjutan adalah sebagai berikut. Pertama, melakukan penelitian lanjutan tentang pengaruh adanya kebijakan daerah terhadap penerima tunjangan profesi, dengan lokasi daerah yang menggunakan kebijakan daerah yang berkaitan dengan penerimaan tunjangan profesi. Penelitian ini sangat berguna untuk mengetahui usaha apa saja yang akan dilakukan guru dalam mempertahankan profesinya sebagai guru agar tidak kehilangan tunjangan profesi yang telah diterima. Kedua, melakukan kajian-kajian yang berkaitan dengan kebijakan daerah yang terkadang dipengaruhi unsur politis, yang disinyalir kekuatan politis itu tidak sejalan dengan kepentingan pendidikan dalam upaya meningkatkan mutu dan kualitas pendidikan.

\section{Daftar Pustaka}

Altsbuler, S. J., \& Webb, J. R. (2009). School social work: Increasing the legitimacy of the profession. Journal of the National Association of Social Workers, 31, 207219.

American Council on Education. (2004). Teacher education program in the united states. ACE/Praeger series on higher education. Washington D: Modoc Press Inc.

Cohen, E. G., Brody, C. M., \& SaponShevin, M. (2004). Teaching cooperative learning. The challenge for teacher education. New York: State University New York Press.

Depdiknas. Undang-Undang No. 14 Tahun 2005 tentang Guru dan Dosen (2005). Jakarta.

Hiley, M., \& Soenarto. (2013). Analisis kebijakan pengembangan sekolah Lukmanulhakeem Yala Thailand. Jurnal Akuntabilitas Manajemen Pendidikan, 1(1), 80-97. Retrieved from http://journal.uny.ac.id/index.php/j amp/article/view/2328

Mendikbud RI. Peraturan nomor 62 tahun 2013 tentang sertifikasi guru dalam jabatan dalam rangka penataan dan penempatan guru (2013).

Mendikbud RI. (2015). Peraturan Nomor 4 Tahun 2015 tentang Ekuivalensi kegiatan pembelajaran/pembibingan bagi guru yang bertugas pada SMP/SMA/SMK yang melaksanakan Kurikulum 2013 pada semester pertama menjadi Kurikulum tahun 2006 pada semester kedua Tahun Pelajaran 2014/2015.

Mendiknas RI. Peraturan Menteri Pendidikan Nasional Nomor 18 Tahun 2007 tentang Sertifikasi bagi Guru 
dalam Jabatan (2007).

Mendiknas RI. Peraturan nomor 39 tahun 2009 tentang pemenuhan beban kerja guru dan pengawas satuan pendidikan (2009).

Moleong, L. J. (2014). Metodologi penelitian kualitatif. Bandung: Remaja Rosdakarya.

OECD-ADB. (2015). Reviews of national policies for education. Education in Indonesia. Rising to the challange. Paris: Publishing OEC.

Presiden RI. Peraturan Pemerintah RI Nomor 74 Tahun 2008 tentang Guru (2008).
Sugiyono. (2014). Metode penelitian pendidikan. Bandung: Alfabeta.

Tilaar, H. A. R., \& Nugroho, R. (2012). Kebijakan pendidikan. Yogyakarta: Pustaka Pelajar.

USAID. (2014). Tata kelola distribusi guru secara proporsional (DGP). Seri pembelajaran dari USAID-KINERJA. Jakarta: USAID.

Weimer, D. L., \& Vining, A. R. (2011). Policy analysis: concept and practice (5th ed.). New Jersey: Pearson Prentice Hall, Inc. 